\title{
Barn som relasjonspartnere:
}

\section{Diskurser om det kulturelt adekvate barnet}

\section{Af OdDbJørg SkjÆr Ulvik}

\section{Hoordan konstrueres diskursen om 'det kulturelt adekvate barnet'? Hverdagslivspraksisene mellom barn og voksne kan analyseres som genevasjonspraksiser; det vil si at kulturelle betydninger av 'barn'og 'voksen' utforskes. Det argumenteres for relevansen av generasjon som analytisk kategori, ved siden av kjønn.}

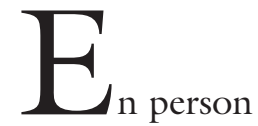

beskriver sin begynnende relasjon til en annen. Det foregår i Norge på slutten av 1990-tallet. Den som forteller er en voksen, en kvinne. Den hun snakker om er et barn, en 13 år gammel gutt, her kalt Alexander. Kvinnen, som her får navnet Sara, er ikke barnets mor i den forstand at hun har født ham, levert hans genmateriale eller har juridisk foreldreansvar for ham. Men hun er i en sosial og praktisk posisjon som ansvarlig omsorgsgiver for ham og deler hverdagslivet med ham, i egenskap av å være hans fostermor. ${ }^{2}$ Hun forteller om forventninger som ikke innfris:

"Det gikk så glatt at det var helt unaturlig og veldig kjedelig. Og veldig provoserende. På en måte tenkte jeg: skal jeg orke dette mer? Gidder jeg dette mer? Som jeg sa til Alexander noen ganger: "Hvem - altså hvem er du? Hvor er du? Kom fram da, så jeg får se hvem du er faktisk!" Det var aldri noe han ønsket seg, han ønsket seg ikke en gang en annen 
type syltetøy til frokostbordet, ikke sant? Spurte aldri om å få noe, spurte aldri om å få penger til en sjokolade, ingenting. Liksom bare å sitte der og godta og godta. Så syntes jeg kanskje det var greiere å ikke ha ham. Jeg følte at han på en måte ikke ville være her, og at hvis vi ikke kunne være sammen på en vanlig måte, så var det ingen grunn til at han skulle fortsette å være her, syntes jeg.

Jeg opplevde det ikke som meningsfylt, en sånn taus statue som går ut og inn på kjøkkenet, og liksom: "Hvordan har du hatt det på jobben i dag da?” Det var liksom det. Og så var det ikke noe mer. Men da er jeg vel kanskje sånn, at jeg stiller så store krav til meg selv og til andre at et sånt forhold ville jeg ikke ha fortsatt. Det må være et ganske bra mål på at det fungerer godt, ellers har det jo ingen hensikt. Da har man det jo bedre alene. Jeg ville jo aldri bli i et forhold der jeg ikke var mer enn middels tilfreds, sånn gjennomsnitlig". ${ }^{3}$

Betydningskategoriene barn og voksen er ikke naturgitte eller uavhengig av historie. De skapes, forhandles, opprettholdes, utfordres og forandres i det livet som barn og voksne lever sammen. Kategoriene barn og voksen konstrueres dikotomt i forhold til hverandre; et barn er en ikke-voksen, en voksen et ikke-barn. Når det i det videre tales om barn og voksne er det å forstå begrenset til barn og voksne som står overfor hverandre i foreldreskapslignende relasjoner. Hverdagslivspraksisene, altså hvordan livet leves, bidrar til å konstituere partene som henholdsvis barn i omsorgsmottakerposisjon og voksen i ansvarlig omsorgsgiverposisjon i en kontinuerlig forpliktende omsorgsrelasjon. I det som gjøres er det alltid et meningsaspekt, enhver praksis har et diskursivt innhold. Diskurser konstitueres av praksiser og er samtidig konstituerende for praksiser (Davies \& Harré 1993, Hall 2001, Søndergaard 2000). Diskurser kan derfor analyseres fram på grunnlag av beretninger om hverdagslivspraksiser. Denne artikkelen handler særlig om betydningska- tegorien barn, og hva som forstås som det kulturelt adekvate barnet i dagens samfunn. Selv om barna inngår som medkonstuktører av mening, er hovedvekten her lagt på de voksne omsorgsgivernes blikk på barna som relasjonspartnere, og det er de voksnes beretninger som er lagt til grunn for analysene. ${ }^{4}$

Når Sara forteller om seg og sin fostersønn er hun et subjekt som forsyner seg av tilgjengelige forståelser om barn og voksne, eller som kulturpsykologen Wertsch (1991) uttrykker det, tar i bruk tilgjengelige kulturelle redskaper i sin meningskonstruksjon. Hun taler innenfor samtidens diskurser om barn, voksne og relasjoner, som utgjør slike kulturelle redskaper. Samtidig tilfører Sara noe nytt og personlig til de mulige forståelsene av hva barn og voksne kan være for hverandre. Det Sara er skuffet over er ikke et vanskelig barn, dårlig oppførsel, eller atferd som må korrigeres. Tvert i mot er gutten for grei og tilpasningsvillig. Hvis hun var fostermor på 1950-tallet, kan vi forestille oss at hennes forventninger ville vært andre. I lys av oppdragelsesbøker fra denne tiden kunne vi anta at snille og lydige fosterbarn skapte mindre bekymring, og satte relasjonen mindre i fare. De kunne snarere tjene som en bekreftelse på sine omsorgsgiveres positive innsats. De kulturelle redskapene som var tilgjengelige for en voksen kvinne i posisjonen som fostermor den gangen var andre enn de Sara har tilgang til i dag, noe som selvfølgelig innebar andre praksiser overfor barn. For å forstå Saras forventninger og skuffelse er det viktig å se hvilket diskursivt univers hun inngår i og er en medskaper av. Dette kan ikke forklares ved personen Sara alene. Det vi blir skuffet over eller glade for, det som făr oss til å oppleve kjærlighet eller likegyldighet i relasjonen til en annen, er preget av våre implisitte og delte forståelser av hvordan relasjoner skal være, hvordan barn skal være, hvordan kvinner skal være og hvordan menn skal være. De implisitte forståelsene, eller diskursene, gir retning til 
hvordan voksne utformer omsorg og utviklingsstøtte for barn, hvilke utviklingsmål de har for barnet og hvilke strategier de bruker for å nå sine utviklingsmål. Samtidig er det slike praksiser som konstituerer diskursene. Voksnes utviklingsstøtte til barn blir altså mer forståelig om vi kjenner til slike betydninger, det blir dermed også deres opplevelse av tilfredshet og skuffelse.

\section{FOSTERFAMILIE SOM}

VOKSEN-BARN-RELASJON - EN VARIANT

Ved å studere hva en gruppe voksne omsorgsgivere prøver å få til for barna de har ansvar for, kan en utforske implisitte barneforståelser, altså diskurser om det kulturelt adekvate barnet. Det empiriske utgangspunktet her er en intervjustudie av barn og voksne som har fătt $\mathrm{i}$ oppgave å danne foreldreskapslignende relasjoner til hverandre, nemlig fosterfamilier. Fosterbarn og fosterforeldre i 18 fosterfamilier er intervjuet gjentatte ganger innenfor en toårsperiode. Intervjuene er rettet mot hverdagslivet de lever, og er en tilpasset variant av livsformsintervjuet (Haavind 1987, 1997). Beretningene om hverdgsliv ga grunnlag for å analysere fram aktørenes meningskonstruksjon. 5

Fosterforeldreskap er et omsorgsarrangement for oppvoksende barn som i Norge administreres av barnevernet. Arrangementet er basert på en familie/foreldreskapsmodell, og dette er den meningspakken partene tilbys når de skal utforme relasjoner til hverandre; mor, far og barn. Utgangpunktet er de implisitte forståelsene av hva det vil si å være mor for et barn, far for et barn, barn for en voksen, foreldre og barn for hverandre. Aktørene i fosterfamilier trekker veksler på de alminnelige forståelsene av foreldreskap når de skal forstå og utforme sin egen situasjon. For partene i fosterfamilier er de kulturelt selvfølgelige forutsetningene for forholdet mellom foreldre og barn brutt, og skal dermed gjenskapes. De voksne skal ikke bare gi barna en kulturelt adekvat utviklingsstøtte. De skal også korrigere og kompensere for den mangelfulle utviklingsstøtten disse barna har vært utsatt for i sine opprinnelsesfamilier. Fosterforeldrene skal bringe barnet inn på et kulturelt akseptabelt utviklingsspor. Det er antropologen Jean Briggs (1991) som uttrykker et kontekstforankret og innholdsfritt utviklingmål slik; i enhver kultur tilstreber de store at barn skal bli sosialt 'upåfallende', eller 'unremarkable' som hun uttrykker det. I mine informanters terminologi uttrykkes dette målet som 'en vanlig unge'. Fosterforeldrenes bestrebelser på å frambringe et slikt barn gir grunnlag for å utforske nettopp hva dette innebærer; hva er den kulturelle oppskriften på 'en vanlig unge' i Norge for tida? Hva er det som kreves av voksne omsorgsgivere for at dette skal være resultatet? Sxrlig tydelig blir de implisitte idealene der resultatet ikke oppnås, der ungen ikke lykkes $\mathrm{i}$ å innfri de voksnes forventninger, og de voksnes bestrebelser ikke fører fram.

Når fosterforeldrskap brukes som case for å utforske mer allmenne kulturelle barneforståelser, er det viktig å påpeke noen viktige forskjeller mellom fosterfamilien som omsorgsarrangement og den tradisjonelle kjernefamilien basert på biologisk slektskap. Fosterforeldreskap skiller seg fra annet foreldreskap ved den oppsigelige kontrakten. I vår forståelse av foreldreskap er kontrakten uoppsigelig, det er ikke legitimt å slutte å være foreldre. Mens vi har språklige uttrykk for eks-koner, eks-menn og eks-svigerforeldre, finnes det er ikke begreper som eks-foreldre og eks-barn. Dette til tross for at det selvfølgelig finnes praksiser der relasjonen mellom foreldre og barn avsluttes. I fosterforeldreskap er mulig midlertidighet et tydeligere tema, men oppsigelse er ikke dermed uten videre legitimt. Dette vil danne andre betingelser for forhandlingene mellom barnet og de voksne enn de som foregår i andre familier. 


\section{FORELDRESKAP SOM KJØNNET OG} TO-GENERASJONELT ARRANGEMENT

Både kjønn og generasjon er kategorier som impliserer en maktulikhet mellom to parter. Det er hensiktsmessig å generalisere analytiske tilnærminger på tvers av disse, modeller utviklet for å utforske kjønnede betydninger kan overføres til studier som bruker generasjon som en sentral kategori. Randi Dyblie Nilsen (2003) påpeker imidlertid at det sjeldnere er omvendt, at barneforskning inspirerer kjønnsforskning.

Generasjon er i denne sammenhengen å forstå som relasjonelle posisjoner som defineres i forhold til hverandre, som foreldre og barn. Hverdagslivspraksisene i fosterfamilier kan utforskes som generasjonspraksiser. Foreldreskapsinstitusjonen er i løpet av de siste ti-årene grundig analysert som et kjønnet arrangement (Andenæs 1996, Lupton \& Barclay 2000). Det vil si at en $\mathrm{i}$ analysen gjør relevant at foreldreskap ikke er kjønnsnøytralt, at foreldre som menn og kvinner har ulike samfunnsmessige betingelser når de skaper seg selv og utformer sine praksiser. Gender practices er et begrep som brukes som analytisk redskap for å belyse hvordan kjønnede betydninger skapes og forhandles i partenes praksiser. Tilsvarende kan begrepet generasjonspraksiser brukes for å utforske partenes posisjoner som barn og voksen. Hverdagslivspraksisene i fosterfamilier, som i andre familier kan også analyseres som kjønnede praksiser. Kjønnede betydninger forhandles både $\mathrm{i}$ utformingen av et foreldreskap, og i utviklingsstøtten til de kjønnede barna. Det er imidlertid en utfordring å analysere foreldreskap som et arrangement som er både kjønnet og to-generasjonelt. $\AA$ romme både generasjon og kjønn i samme analyse er en relevant ambisjon, som realiseres i relativt få studier (Nilsen 2003). I denne artikkelen har aksen generasjon fått prioritet framfor aksen kjønn, uten at den siste dermed gjøres irrelevant.

\section{TRE DISKURSER OM BARN}

På grunnlag av analysene i studien av fosterforeldreskap har jeg benevnt tre diskurser om det kulturelt adekvate barnet, som altså er det barnet fosterforeldrene skal frambringe;

diskursen om det gjensidighetskompetente barnet, det selvskapende barnet og barnet med begrenset ansvar.

Videre skal vi se på hvordan disse på varierende måter både gir retning til og konstitueres ved fosterforeldrenes praksiser overfor barna. Vi skal se når diskurser er forenlige og når de står i motsetning til hverandre, og hvordan spenning mellom dem oppstår. I menneskenes tale er diskursene til dels innfiltrede i hverandre, og det er bare for framstillingsformål de presenteres i rekkefølge.

\section{GJENSIDIGHET OG SELVSKAPING - NYE FORVENTNINGER TIL BARN}

Vi skal vende tilbake til refleksjonene til Alexanders fostermor Sara. Hun forventer at barnet skal framstå som et autonomt og intensjonalt selv, altså innenfor diskursen om det selvskapende barnet. Forventningene hennes rommer også at han skal ønske seg noe som hun kan gi og som hun ønsker å gi ham. Dette er kriterier for at relasjonen kan være tilfredsstillende for henne, noe som gjøres til en betingelse for å opprettholde den. Den voksne vurderer og synliggjør både seg selv og barnet som relasjonspartnere. At fosterrelasjonen er utilfredsstillende for en av partene skaper i Saras forståelse legitimitet for å oppløse den. Gjensidighet skapes ved at begge parter framstår som intensjonale, og at deres bidrag passer sammen. Sara peker selv på at hun har analoge forventninger til relasjonen til fosterbarnet og til parforhold. Men hennes forventninger til hvordan barnet skal skape seg selv og uttrykke dette overfor henne gjør ikke dermed alder og gene- 
rasjon irrelevant. Det er ikke innholdet $\mathrm{i}$ forventningene som er likt, det er snarere modellen for relasjoner som er den samme som for en voksen-voksen-relasjon. Frittstående, selvforsynte individer representerer et tilbud til hverandre. Likestilthet er en implisitt premiss.

'Den rene relasjon' består ifølge Giddens (1993) av et møte mellom autonome individer, der legitimiteten består av gjensidig tilfredshet. Plikt, avhengigheter, behov og sårbarhet er nedtonet $\mathrm{i}$ denne relasjonsdiskursen. Individer vektlegges framfor generasjonsmessige og aldersmessige posisjoner, og forskjellene mellom barn og voksne i familierelasjoner nedtones. Det kan stilles spørsmål ved om selve betydningskategoriene barn og voksen til en viss grad oppløses og blir irrelevante innenfor denne relasjonsdiskursen. Slike diskursive endringer kan forstås som en demokratisering av forholdet mellom barn og voksne, en større grad av likestil-ling. På det deskriptive plan kommer slike tendenser fram i begreper som 'forhandlingsfamilien', som betegner endringer i praksiser og idealer i retning av større demokrati og medbestemmelse i barns forhold til sine foreldre (Dencik \& Schultz Jørgensen 1999, Sommer 1997). Imidlertid vil barns avhegighet av voksne mindre synlig innefor en slik relasjonsdiskurs. Mens barn franstår mer som individualiserte relasjonspartnere, blir maktulikheten mellom familiære relasjonspartnere fra ulike generasjonkategorier tildekket. Denne type endringer i forståelse av intime relasjoner er beskrevet og analysert ikke minst i feministisk litteratur (for eksempel Holter 1982). Diskursive endringer i individualiserende retning bidrar til en 'usynliggjøring' både av kjønn og generasjon i intime relasjoner, og utgjør derfor nye analytiske utfordringer. Når forskjellene mellom kvinner og menn, barn og voksne neddempes i aktørenes egen forståelse, må en søke nye grep for å analysere fram hvordan disse sosiale kategoriene tillegges mening (Søndergaard 1996).
Det er viktig å påpeke at Sara ikke er spesielt krevende eller lite imøtekommende. Hennes beretning kan snarere representere og varsle endringer i hvordan kategoriene barn og voksen konstitueres, et eksempel der nye forventninger til barn blir tydelige. En type forventning som i denne studien kommer tydeligst fram i Saras beretning kan rommes i det jeg betegner som diskursen om det gjensidighetskompetente barnet. Det er en forventning om at barnet skal yte et bidrag som skal ha som resultat at den voksne opplever at det er en form for gjensidighet mellom de to. Sara representerer her en diskurs som er tilgjengelig for alle som inngår i relasjoner nå for tiden. De fleste fosterforeldrene gir på ulike måter uttrykk for forventninger om gjensidighet i relasjonen til barnet. Hva som forventes å være barnets bidrag varierer. Fosterforeldrene har også ulike forståelser av hva de selv skal bidra med, om de skal bidra til barnets gjensidighetskompetanse. Noen innlemmer det i sitt ansvar som voksen omsorgsgiver å bidra til at barnet utvikler denne kompetansen, mens andre, som Sara, gjør kompetansen til en forutsetning for relasjonen. For alle gjelder det at gjensidighetskompetanse er et utviklingsmål de har for barnet. Dette er begrunnet i deres egen relasjon til barnet, men barnets forhold til andre barn og andre voksne er også i fosterforeldrenes oppmerksomhet. Vi skal nå se nærmere på variasjonen i forventningene om gjensidighet.

\section{Emosjonell gjensidighet: Genuine folelsesut- trykk og forståelse av andre}

Det er flere av de voksne som opplever skuffelse i relasjonen til fosterbarnet, slik 7 år gamle Marias fosterforeldre gjør. Fosterfaren Truls forteller:

"Hun er liksom ikke glad i oss, det er hun ikke. Det er omtrent som på et internat. ... Det er helt tydelig at man skal ikke trenge seg inn i hennes privatliv, for å si det slik, det vernes. Hun sier god natt og gir en klem, det er 
en innlært øvelse. Hun gjør ikke det med følelsene. Men en klem som er like festlig å få som det lederne i Kreml holder på med. Det er like personlig. Det er ikke noe vondt ment, det er bare ikke noe innhold."

Fostermoren Tove forteller: "Med Tom (et tidligere weekendbarn familien har hatt) nådde vi fram. Han skjønte når jeg var sint, han skjønte når jeg var glad. Maria skjønner ikke når jeg er glad eller når hun gjør meg lei seg."

Disse fosterforeldrene beskriver sine følelser og gjensidighetsforventninger, og ønskene om å bli forstått som omsorgsgivere, - men også som relasjonspartnere. Her vurderes den emosjonelle kvaliteten og intensjonen i barnets praksis. Hun gir ikke en klem med følelser, hun ser ikke når hun gjør noen lei seg. Praksisformer som å sitte på fanget og gi klemmer fortolkes vanligvis som nærhetsmarkører, som uttrykk for tilhørighet. Slik blir de ikke fortolket her. Det er ikke praksisformene, væremåtene i seg selv som vurderes, men intensjonaliteten i barnets handlinger.

I beretningene til Marias fosterforeldre framstilles både barnet og de voksne tydelig som relasjonspartnere, som individuelle parter med intensjoner, slik vi også så det $\mathrm{i}$ Saras fortelling. Når det snakkes om "barnets privatliv", understrekes den individualiserte forståelsen av et barn. Det legges ned en omfattende innsats $\mathrm{i}$ å forstå og fortolke barnet. Samtidig går forventningene som rettes mot barnet ut på selv å bli forstått, et barn er en part man kan rette slike forventninger mot. Dette kan forstås som en større grad av symmetri i voksen-barnrelasjonen. Gjensidigheten som forventes og som når den mangler skaper skuffelse, er i dette tilfellet en emosjonell gjensidighet. Men gjensidighetsforventningene kan som vi skal se også ha et annet innhold.

Barnet som partner $i$ eget utviklingsprosjekt Gunnar og Grete, 13 år gamle Fridas fosterforeldre, har en annen variant av gjensi- dighetsforventninger til barnet. Her går forventningene ut på at barn og voksne skal være partnere $\mathrm{i}$ et felles prosjekt; å jobbe med barnets utvikling. Når barnet undrar seg dette partnerskapet, forstås det som manglende gjensidighet og de voksne blir i tvil om relasjonen. Grete forteller:

"vi har faktisk truet med det, (at hun ikke skulle få være her lenger). Vi ble så sinte på henne på grunn av sånne episoder som gjentok seg flere ganger. Og da fortalte vi at hvis ikke hun var interessert $\mathrm{i}$ å gjøre noe som helst selv for å hjelpe seg selv, når vi sto på, for vi sa jo sånne ting, og forklarte at for at hun skulle få det enklere, og ikke for vår egen del, så sa vi at hvis du tror at vi gidder dette her hvis ikke du er interessert i å få det bedre, hvorfor i alle dager skal vi være det? Vi får ingen glede av at du greier deg her i livet, liksom sånn, vi sa det ikke sånn da, men tok slike eksempler, at det var henne det dreide seg om. Det var ikke vi som tapte på noe som helst, det var ikke vi som fikk det vondt hvis hun flyttet. Vi var faktisk så harde. Vi truet vel nesten da at, hvis du fortsetter sånn, så setter vi deg på en buss og sender deg av gårde. Vi orket ikke mer altså, rett og slett. Og jeg tror hun trengte en liten sånn om at hun er ikke alt her i verden. Det finnes en grense. At hun må gi litegrann tilbake hvis dette skal gå. Det er ikke bare vi. Jeg føler vel at vi gjør det vel aldri, men det må bare ut. Hun må være klar over det. Du kan diskutere om det er rett å bruke en slik trussel overfor en unge, men akkurat der og da så tror jeg det var viktig for henne å få fingeren i jorda att. Vi opplever at Frida er ungen vår, men vi vil ikke kalle oss for foreldre. Hvis hun hadde vært mindre spesiell, hvis vi hadde fătt igjen mer fra henne, så kanskje. En annen unge slår i bordet og sier jeg vil, jeg vil, og det kommer vi aldri til å oppleve med henne.”

I de voksnes forventninger til barnets bidrag er gjensidighet en nødvendighet. En viss grad av gjensidighet er også det som konstituerer foreldreskap. Gjensidigheten 
her, at "hun må gi litegrann igjen" innebærer også emosjonell bekreftelse, men ser ikke ut til å være begrenset til det. I denne fortellingen innebærer gjensidighet også en tilslutning fra barnet til de voksnes utviklingsmål for henne. Det forventes at barnet aktivt bidrar til disse målene, selv om fosterforeldrene er innstilte på yte et omfattende bidrag. Forventningen er at barnet skal arbeide med sin egen utvikling, slik at det blir et fellesprosjekt mellom de voksne og barnet. Det er på denne måten de forventer at hun skal "gi noe igjen". Det lages et skarpt skille mellom "dine" interesser og "våre" interesser, altså en individualisering av interesser. Det snakkes om en grense, som her må forstås som noe annet enn det som i familier flest benevnes som "grensesetting". Grense kan her fortolkes som en tålegrense hos den voksne for manglende gjensidighet. Men vi kan også se en annen grense som tangeres. Illegitimiteten i å si opp kontrakten i en voksen-barn-relasjon framgår ved de selvrefleksive, selvkritiske komentarene, og forsikringen om at bruddet ikke blir realisert. Men muligheten for brudd er en annen enn den ville være i en konvensjonell foreldre-barn-relasjon. Konflikter om ulikhet i utviklingsmål mellom barn og foreldre er et kjent fenomen også $i$ andre familier. Men i slike familier vil ikke konfliktene på samme måte inngå i en forhandling om relasjonens fortsatte eksistens.

Dynamikken mellom diskursene, selvskaping og gjensidighet, blir også tydelig her. Hvis barnet er mer selvrepresenterende, "sier mer fra" kunne det tenkes at de opplevde det mer som foreldreskap. Når fostermor for eksempel slites ut av kamper rundt dusjing og sjampo-bruk, er det ikke bare på grunn av lyving og luring, men også den manglende egeninteressen fra barnets side. Når de voksne truer med å avslutte relasjonen henvender de seg til henne som det autonome, avgrensede individet de vil hun skal bli. Den måten hun ved sin holdning til hygiene realiserer seg selv som autonom og avgrenset, blir ikke gitt gyldighet. Hun har et annet utviklingsprosjekt enn fosterforeldrene.

\section{SELVSKAPING SOM PROSJEKT - OGSÅ FOR BARN}

I fortellingene har vi hørt både diskursen om det gjensidighetskompetente barnet, og diskursen om det selvskapende barnet. Det som vanskeliggjør relasjonen i Saras forståelse er Alexanders manglende selvrepresentasjon, hans lave profil, hans utilstrekkelighet overfor den kulturelle forpliktelsen “å være seg selv". Det samme ser vi når det gjelder Frida, selvskaping fra barnets side konstituerer foreldreskap. Innforstått er at man har et selv man kan være, eller det finnes et selv man kan finne (Bauman 1996, Gullestad 1997), og at forpliktelsen også omfatter barn. Diskursen om det selvskapende barnet innebærer den kontinuerlige produksjonen og utformingen av et unikt selv som prosjekt. Slik vi ser det i flere av fortellingene er det et dynamisk forhold mellom de to diskursene; selvskaping er en forutsetning for gjensidighet. I Saras tale er også hennes eget selvprosjekt sentralt, hun konstruerer hvem hun er og hvem hun ikke vil være ved sin praksis i relasjonen til et barn. Foreldreskap som selvkonstituerende praksis er framhevet av flere forfattere (Bauman 1996, Lupton \& Barclay 2000). I fosterforeldreskap kan den selvkonstituerende praksis komme tydeligere fram. Fosterforeldreskap blir en kontekst for selvskaping som både ligner og er forskjellig fra biologisk foreldreskap.

\section{DET KJØNNS- OG ALDERSADEKVATE BARNET SOM UTVIKLINGSMÅL}

Når vi snakker om det kulturelt adekvate barnet er det nødvendig å presisere ytterligere hva som ligger i dette. Det kulturelt adekvate barnet er verken kjønns- eller aldersløst. I omsorgsgiveres utviklingsmål inngår den aldersadekvate jenta eller den al- 
dersadekvate gutten. Kjønn og alder er grunnleggende sosiale kategorier, som på ureflekterte måter gir retning til egne subjektiverende bevegelser og andres fortolkninger. I et seinmoderne samfunn er kjønnede væremåter ikke komplementære. Menn og kvinner, gutter og jenter, har ikke normativt ulike atferdsrepertoarer, selv om praksisene kategoriene i mellom kan bli svært ulike. Menn og kvinner, gutter og jenter kan i prinsippet gjøre det samme, betydningen av partenes kjønn forhandles kontinuerlig i interaksjon, $\mathrm{i}$ parforhold og $\mathrm{i}$ barnefelleskap. Kjønn er en kraftfull fortolkningsramme for partenes væremåter, identiske praksiser blir fortolket ulikt når de utøves av en mannlig eller en kvinnelig aktør (Andenæs 1996, Gulbrandsen 1998, Haavind 1982). Søndergaard (1996) introduserer termen kjønn som metakode. Kjønn forstås som en kulturelt medierende og sosialt ordensskapende konstruksjon. Men det er ikke på en direkte og konkret måte at anvisninger for væremåter gis. Orden skapes fleksibelt i forhold til et mer abstrahert kodesystem.

Tale, 6 år, oppfører seg verken kjønnseller aldersadekvat når hun møter sine fosterforeldre for første gang. Fosterforeldrene forteller: "Hun er tøff, kledd i silkeshorts og boksehansker, opptatt av kamp og krigsleker. En kjøper ikke boksehansker og sverd og skjold til slike unger, da prøver en heller å myke litt opp”. Moren og beredskapshjemmet forsterket heller det guttete ved henne, ved å gi henne figurer og gutteleker, som fosterforeldrene for så vidt ikke synes er noe OK for gutter heller. Fosterforeldrene har tatt bort krigslekene gradvis. De bruker også å henvise til andre barn; "Ser du noen av venninnene dine leke med dette, Tale?" Jenter behøver ikke å leke med dokker, men det var ingenting som var jentete ved Tale. I lekebutikken går hun rett på guttetingene. I klesbutikken gjør hun også det. Fostermor sier: "Her er jenteavdelingen." Tale kan gjerne klatre i trær og gjøre slike guttete ting, og hun kan gjerne ha jentetøy som egner seg for slike aktiviteter. Første skoledag syntes de det var viktig at hun hadde kjole, ikke fordi de var så opptatt av det selv, men fordi hun ville merke seg ut hvis hun var den eneste som kom i bukser. De legger et visst press på henne når det gjelder klær, sier at du skal ha på deg dette, men det er fordi de ser at det går, at hun ikke får en fæl dag etterpå. Da hun kom, brukte hun en sutteklut. Den var ekkel og uhygienisk. Fosterforeldrene vasket den og byttet den ut med en ny, og etter hvert satte de strengere restriksjoner. De argumenterer med at hun er for stor til å bruke sutteklut, og lykkes etter hvert i å få henne til å slutte. Når de skal oppsummere hvordan det har gått, ser de at nå smiler Tale og en ser at det er et slikt godt smil. Hun har blitt ei veldig myk, koselig og rolig jente. Hun aler til og med til langt hår, ber om å ha hestehale. Hun så at venninna hadde det.

Tales fosterforeldre kan ikke anklages for å ha konvensjonelle kjønnsforestillinger, snarere kan de forstås som kultursensitive. Kjønnsadekvat selvpresentasjon er ikke et mål i seg selv, men tilstrebes med begrunnelse i de sosiale konsekvensene av å opptre inadekvat. Strategiene de bruker er gradvise, sensitive og målrettede endringsframstøt. Andre barn brukes som modeller. " $\AA$ være for stor" brukes som argument i forhold til ikke aldersadekvat atferd, som suttekluten ansees som, en konkret strategi som er vanlig for foreldre. Barnets "feilatferd" fortolkes som mangelfull opplæring, ikke som iboende personlige egenskaper, og oppfattes dermed å være foranderlig (Haavind 1987).

\section{DISKURSEN OM BARNET MED BEGRENSET ANSVAR}

I de empiriske eksemplene har vi sett at barn tillegges et ansvar for sin selvframføring. Dette kan fortolkes som en bevegelse i retning av mer ansvar for dem som utgjør kategorien barn. Men spørsmålet om ansvar 
er mer komplekst, det gir ikke mening å tale om 'mer' eller 'mindre' ansvar for barn langs en enkel akse. En liten praksisberetning kan illustrere dette:

Bjørnars fostermor forteller at det er hun som smører matpakke til 11-åringen. Hun sier at dette har hun bestemt seg for, for hun vil vise gutten at det er de voksne som skal ha ansvaret. Han har en historie med omsorgssvikt, det å måtte klare seg selv og ha ansvar for mindre søsken. Derfor synes fostermor at det er viktig å vise han at slik er det ikke lenger. Nå er det forskjell på voksne og barn, og nå skal han avlastes for et ansvar som er for stort for ham. Anbefalinger fra saksbehandler går ut på at gutten skal lære å klare seg selv

Denne fostermoren sørger for barnets ernæring ved å smøre matpakke til ham hver morgen. Men å organisere omsorgen på akkurat denne måten er ikke begrunnet $\mathrm{i}$ ernæring. Hennes handlemåte kan forstås som generasjonspraksis; hun 'gjør' generasjon på denne måten. Hennes forståelse av det vanlige og ønskelige, er barns relative ansvarsfrihet og voksnes ansvar for barn, dette kan benevnes som diskursen om barnet med begrenset ansvar. Hun benytter denne anledningen til å bidra til å nå et annet og mer overordnet utviklingsmål. Matpakkesmøringen kan derfor sies å inngå i et prosjekt for kulturell korreksjon; utviklingsstøtten har som hensikt at han skal bli et kulturelt adekvat barn. Strategien er begrunnet $\mathrm{i}$ at det dreier seg om et fosterbarn, men samtidig gjør denne unntaksstrategien de allmenne betydningene mer tydelige. Her kompenserer fostermoren "uvanlighet", altså at han har hatt for mye ansvar, med en overdose av "vanlighet" når det gjelder foreldre-barn-relasjoner. Hun oppfatter selvstendighet som et sentralt utviklingsmål på den allmenne utviklingsagendaen for barn, og hun antar i tråd med dette at barn på Bjørnars alder normalt forventes å skulle lære å smøre matpakke selv. Fostermor reserverer seg ikke fra dette utviklingsmålet. Men i det spesielle tilfelle med Bjørnar ser hun det som et overordnet utviklingsmål at barnet får en adekvat forståelse og utforming av hva det vil si å være i posisjonen barn. Også andre fosterforeldre taler innenfor diskursen om barnet med begrenset ansvar. Begrenset ansvar inngår i selve konstitueringen av kategorien barn; "Nå er hun mer barn", "han var en voksen i barnham". Det refereres da til barn som har beveget seg i retning mindre ansvar for andre mennesker, en bevegelse deres fosterforeldre har bidratt til.

Artikkelens ulike fortellingene kan lett forstås som fortellinger om ulike typer omsorgsgivere, noe som ikke er hensikten i en analyse som dette. Enhver kategorisering innebærer en taus normativitet, den ene typen omsorgsgiver kan dermed forstås som mer moralsk korrekt enn andre. Det dreier seg snarere om omsorgsgivere som forholder seg personlig og subjektivt til motsetningsfylte diskurser, som posisjonerer seg i forhold til aktuelle diskurser (Davies \& Harré 1990). Disse fosterforeldrene, og vi selv, beveger oss hele tiden mellom ulike diskurser. Diskursen om det selvskapende barnet og diskursen om det gjensidighetskompetente barnet er ikke nødvendigvis inkompatible med diskursen om barnet med begrenset ansvar. Voksne omsorgsgivere kan posisjonere seg innenfor alle disse diskursene. Det kulturelt adekvate barnet konstitueres ved å være selvskapende, gjensidighetskompetent og ha begrenset ansvar. Det er snarere til den allmennkulturelle utviklingsagendaen de diskursive spenningen kan lokaliseres.

\section{BEHOVET FOR KONTINUERLIGE}

\section{ANALYSER AV DISKURSER OM DET}

\section{KULTURELT ADEKVATE BARNET}

Relasjonen mellom foreldre og barn, er særlig utsatt for naturalisering. Måten barn og foreldre forholder seg til hverandre forstås som 'naturlig'. Dette fenomenet er også utsatt for teoretisk naturalisering. Det er derfor påkrevet å løpende analysere hvor- 
dan barn og voksne innenfor kulturelle kontekster forholder seg til de gjeldende diskursene om barn, voksne og relasjoner.

Bildene i artikkelen er ikke varige, de er snarere øyeblikksbilder. Diskurser om barn og relasjoner vil være i stadig bevegelse, de vil endre seg i takt med barn og voksnes endrede praksiser overfor hverandre. Med utgangspunkt i fortellingene kan vi ikke snakke om en entydig tendens til utvidet ansvar, like lite som en kan fastslå entydige tendenser til mindre ansvar. Det kan snarere se ut til at det ansvar barn kan pålegges, er mer subtilt enn 'ansvar for seg selv'/ansvar for egen funksjon. Barn avlastes for praktisk ansvar for seg selv, de mottar mer omsorg og mer service, de avlastes i omsorgsansvar for andre, eldre og yngre, men pålegges et mer omfattende ansvar for sin løpende selvframføring, og dermed også for eget bidrag til relasjonene de inngår i. At relasjonene til barna også berører de voksnes selvskapingsprosjekter, kan gjøre relasjonene mer sårbare. Ferdigheter og kompetanser på ett nivå kan ikke vurderes isolert, men må sees i lys av et nettverk av til dels motstridende diskurser.

\section{Noter}

1. Artikkelen er en bearbeidet og forkortet utgave av et kapittel i boka Kulturpsykologi. Bevegelser $i$ livsløp. (Thorsen og Toverud, 2002). Kapitlets tittel er "Generasjonspraksiser. Diskurser om det kulturelt adekvate barnet.” Artikkelen er gjengitt med tillatelse fra forlaget.

2. 'Fostermor' tilsvarer den danske betegnelsen 'plejemor'. 'Fosterfamilie' tilsvarer på samme måte 'plejefamilie'.

3. Intervjuutdragene er redigerte for å være mer lesbare. Intervjuerstemmen er tatt bort. De er likevel så nær informantenes muntlige tale som mulig. 4. I Ulvik (2005) er også barnas beretninger analysert. Barnas selvkonstruksjon som fosterbarn og deres bidrag i forhandlingene om relasjoner til sine fosterforeldre er her mer omfattende behandlet. 5 . For en nærmere redegjørelse for den metodologiske tilnærmingen se Ulvik (2005).

\section{LITTERATUR}

- Andenæs, A. (1996): Barn og foreldre i forandring. Pedagogisk forlag, Oslo.

- Bauman, Z. (1996): "From pilgrim to tourist or a short history of identity" i S. Hall \& P.du Gay (eds.): Questions of Cultural Identity. s.18 - 36. Sage, London.

· Briggs, J (1991): "Mazes of meaning: The exploration of individuality in culture through individual constructs" I: Bryce \& Rush Boyer (eds.): The Psychoanalytic Study of Society, vol. 16. Hillsdale, Analytic Press, New Jersey.

- Davies, B. \& Harré, R. (1990): "Positioning: The discursive production of selves" Journal for the Theory of Social Behaviour, 20, 43 - 63.

- Dencik, L. \& Schultz Jørgensen, P. (red.)(1999): Børn og familie $i$ det postmoderne samfund. Hans Reitzel, København.

- Giddens, A. (1993): The transformation of intimacy: Sexuality, love and eroticism in modern societies. Polity Press, Cambridge.

- Gulbrandsen, L.M. (1998): I barns dagligliv. En kulturpsykologisk studie av jenter og gutters utvikling. Universitetsforlaget, Oslo.

. Gullestad, M. (1997): "From "Being of use" to"finding oneself": Dilemmas of value transmission between generations in Norway" I M. Gullestad \& M. Segalen (eds.) Family and kinship in Europe. Pinter, London.

- Hall, S. (2001). Foucault: Power, knowledge and discourse. I Wetherell, M., Taylor, S. \& Yates, S.

(eds.) Discourse theory and practice. A reader. s. 72 - 82. Sage, London.

- Holter, H.(red) (1982): Kvinner i fellesskap. Universitetsforlaget, Oslo.

- Haavind, H. (1982): "Makt og kjærlighet i ekteskapet” I R. Haukaa, M. Hoel og H. Haavind (red.). Kvinneforskning: Bidrag til samfunnsteori. Universitetsforlaget, Oslo.

- Haavind, H. (1987): Liten og stor: Mødres omsorg og barns utviklingsmuligheter. Universitetsforlaget, Oslo.

- Haavind, H. (1997): Presenting the life mode interview. Upublisert manus. Psykologisk Institutt, Universitetet i Oslo.

- Lupton, D. \& Barclay, L. (eds.)(2000): Constructing fatherhood: Discourses and experiences. Sage, London.

- Nilsen, R.D. (2003): “Barn og kvinner, barndom og kjønn” Kvinneforskning, 3, 94-115.

- Sommer, D. (1997): Barndomspsykologi: Utvikling $i$ en forandret verden. Pedagogisk forum, Oslo.

. Søndergaard, D.M.(2000): "Detabiliserende diskursanalyse: Veje ind i poststrukturalistisk inspire- 
ret empirisk forskning" I H. Haavind (red.):

Kjønn og fortolkende metode. Metodiske muligheter $i$ kvalitativ forsknin. Gyldendal, Oslo.

- Søndergaard, D.M. (1996): Tegnet på kroppen.

Køn: Koder og konstruktioner blandt unge voksne $i$ Akademia. Museum Tusculaneums Forlag, København.

- Ulvik, O.S. (2005): Fosterfamilie som seinmoderne omsorgsarrangement: En kulturpsykologisk studie av fosterbarn og fosterforeldres fortellinger. Avhandling for dr.psychol-graden, Psykologisk institutt, Universitetet i Oslo.

- Wertsch, J. (1991): Voices of the mind. A sociocultural approach to mediated action. Harvester Wheatsheaf, London.

\section{SUMMARY}

Parental relationships are to a great extent theoretically naturalised, in psychology as well as in other social sciences. This article aims to analyse parental relationships as culturally and historically situated. The meaning of being a child and a responsible caregiver related to one another are negotiated in eve- ryday life practices in continual care relationships between children and adults. Discourses of children and relationships are cultural tools for the participants of those practices. This paper will focus on adult expectations to children. The analysis is based on an interview study with adults and children living in foster families. In foster families, what is taken for granted in other families, will be more explicit. Thus, it is a strategic area to explore cultural meaning of adultchild relationships. The article elaborate "the discourse of the child with limited responsibility", "the discourse of the child competent of reciprocity", and "the discourse of the self constructing child", discourses that are dynamically related.

Oddbjørg Skjær Ulvik

Cand.psychol

Førsteamanuensis

Høgskolen i Oslo

Avd. for økonomi, kommunal og sosialfag 